\title{
Formation of monazite-(Ce, La) by fluid-apatite interaction: the Floresta Azul Alkaline Complex, Bahia, Brazil
}

\author{
Jailson Júnior Alves Santos ${ }^{1,2 *}$ (D), Herbet Conceição $0^{1,2,3}$ (D), \\ Marcel Vinícius Santos Leandro ${ }^{2}$ (D), Maria de Lourdes da Silva Rosa ${ }^{2,3}$ (D)
}

\begin{abstract}
Monazite is a common accessory mineral in the Floresta Azul Alkaline Complex, occurring in three different rock types, which form this batholith: nepheline syenite, granite and fenite. Two compositional types of monazite can be found: monazite- $(C e)$ and monazite-(La), the latter being found only in syenites. Monazite occurs in close association with apatite as anhedral crystals ranging in size from 0.1-100 $\mu \mathrm{m}$, and textures indicate different genetic processes. In nepheline syenite, monazite is closely related to ancylite and apatite, as a late crystallizing phase. Monazite occurs in granites as pore fillings in apatite and was formed by the remobilization of rare earth elements (REE) from apatite by late $\mathrm{CO}_{2}-$ rich fluids. In fenite, monazite appears as acicular crystals, parallel to apatite's crystallographic c-axis formed by exsolution from apatite by metamorphism. The data show that the monazite genesis was closely related to the activity of fluids associated either with the final stages of crystallization of nepheline syenite and granite or with fenitization of country rock.
\end{abstract}

KEYWORDS: Monazite; Mineral chemistry; Alkaline rocks.

\section{INTRODUCTION}

Monazite is a rare earth element (REE) mineral with varied composition and morphology. It usually occurs as an accessory mineral in a number of rock types (Deer et al. 1992), and due to its high resistance to weathering, it can commonly be found in sedimentary debris. It was discovered in the mountains of Ilmen, in Miass (Russia), being named by Breithaupt in 1829 (Overstreet 1967), that used the Greek word $\mu$ ovó $\zeta \varepsilon l v$ (monazein), that means to be solitary, a clear reference to its rarity in that period.

The monazite group is composed of arsenates, phosphates and silicates with monoclinic structure. The general formula for the group is $\mathrm{ABO}_{4}$, in which $\mathrm{A}=\mathrm{REE}^{3+}, \mathrm{Th}^{4+}, \mathrm{U}^{4+}, \mathrm{Y}^{3+}$ and $\mathrm{B}=\mathrm{P}^{5+}, \mathrm{As}^{5+}, \mathrm{Si}^{4+}$ (Fleischer et al. 1990). There are four varieties of monazite, based on their REE content: monazite-(Ce), monazite-( $\mathrm{La})$, monazite-( $\mathrm{Nd}$ ) and monazite-( $\mathrm{Sm})$. It usually forms solid solution with cheralite-[(Ca, Ce, Th) $\left.(\mathrm{P}, \mathrm{Si}) \mathrm{O}_{4}\right]$ and huttonite $\left[\mathrm{ThSiO}_{4}\right]$ (Linthout 2007). Its structure preferably incorporates light REE, whereas xenotime is the heavy REE phosphate ( $\mathrm{Ni}$ et al. 1995). Monazite is considered as one of the most important REE deposit minerals (Toledo et al. 2004).

Monazite generally occurs as an early crystallizing mineral in magmas (e.g., Montel 1993), but it can also be formed by processes resulting from reaction between apatite crystals and fluid such as dissolution, hydrothermalism and metassomatism (Harlov 2015). Monazite is a useful tool for studying crustal processes, being used for geochronology (e.g., Harrison et al. 1995), as an indicator of magmatic temperature (e.g., Montel 1993), in the investigation of metamorphic events (e.g., Kelsey et al. 2008) and for the inference of petrogenetic relations (Rapp \& Watson 1986, Wark \& Miller 1993).

In petrographic studies carried out on rocks from the Floresta Azul Alkaline Complex (FAAC), we observed that apatite crystals systematically present distinctive regions with irregular shapes rich in tiny high relief mineral inclusions,

\footnotetext{
${ }^{1}$ Programa de Pós-Graduação em Geologia, Universidade Federal da Bahia - Salvador (BA), Brazil. E-mail: jailson_jras@hotmail.com

${ }^{2}$ Labortório de Petrologia Aplicada à Pesquisa Mineral, Universidade Federal de Sergipe - São Cristóvão (SE), Brazil. E-mail: marcel.leandro@hotmail.com

${ }^{3}$ Programa de Pós-Graduação em Geociências e Análise de Bacias, Universidade Federal de Sergipe - São Cristóvão (SE), Brazil.

E-mail:herbet@ufs.br,lrosa@ufs.br

*Corresponding author.
}

Manuscript ID: 20180069. Received on: 06/14/2018. Approved on: 10/01/2018. 
most of which identified as monazite on the scanning electron microscope (SEM).

In this paper, we described and discussed the textures, compositional variations and the genesis of monazite in the nepheline syenites, granites and fenites from the FAAC.

\section{THE FLORESTA AZUL ALKALINE COMPLEX}

FAAC is a batholith belonging to the Alkaline Province of South Bahia state (SBAP) (Fig. 1A). This province consists of Neoproterozoic alkaline massifs aligned in a NE-SW direction for $200 \mathrm{~km}$. It extends from the town of Ilhéus, on the Atlantic coast, southwards to Itarantim, near the borderline of Minas Gerais state (Rosa et al. 2007). These intrusions include batholiths, stocks and dykes of foid syenites, litchfieldites, monzonites and granites plus hypabyssal rocks (e.g., phonolite, trachyte, tinguaite, basalt and rhyolite), with predominance of $\mathrm{SiO}_{2}$ undersaturated syenite (Rosa et al. 2007).

\section{Geological setting}

The FAAC (Fig. 1B) is located on the northern part of the SBAP and outcrops over an area of $200 \mathrm{~km}^{2}$ (Fig. 1C). The contact with the metamorphic basement is abrupt, and the presence of xenoliths of granulitic country rock and fenites was reported (Martins \& Santos 1997). The complex is formed by two distinctive intrusions separated by faulting (Rosa et al. 2003).

On the western part of FAAC, there is a syenitic intrusion with an outcrop area close to $70 \mathrm{~km}^{2}$ (Fig. 1C). The syenite, which was dated at ca. $688 \pm 10 \mathrm{Ma}$ (Rosa et al. 2003), has a coarse isotropic hypidiomorphic texture which locally shows magmatic flow structure marked by oriented crystals of alkali feldspar. The massif contains quartz-bearing syenites at the border, and quartz volume gradually decreases towards the central area, giving place to nepheline-bearing syenites. Further, inwards the nepheline-bearing syenites are succeeded by sodalite syenite and sodalitites in the central part of the massif (Santos 2016). Nepheline and perthitic alkali feldspar are essential minerals in syenites. The main mafic mineral is annite, with subordinate aegirine-augite and hornblende. Cancrinite and most crystals of sodalite are formed by reactions between late fluids and nepheline. Crystallization of calcite is synchronous to cancrinite formation pointing out to the presence of fluids with $\mathrm{CO}_{2}$ in the latest phases of syenite crystallization (Santos 2016).

Granites dated at 696 $\pm 11 \mathrm{Ma}$ (Rosa et al. 2003) occur in the eastern part of the FAAC (Fig. 1C), and spread over an area of $130 \mathrm{~km}^{2}$. It shows a medium- to coarsegrained allotriomorphic texture with Fe-biotite being the dominant mafic although aegirine-augite is locally found. Dioritic enclaves, as well as magmatic structures indicative

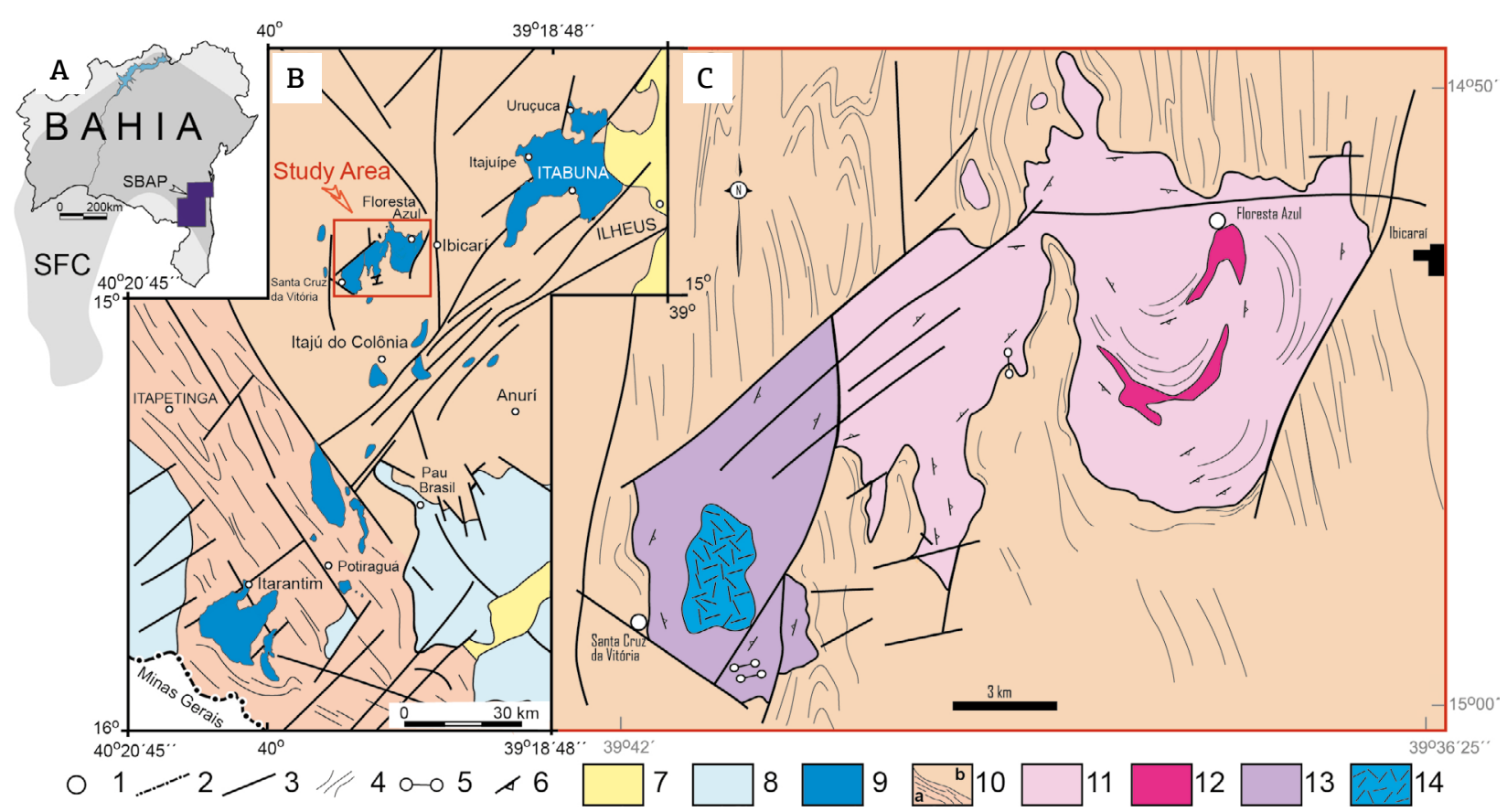

1: city; 2: interstate limit; 3: fracture/fault; 4: lineament detected on remote sensors; 5: dikes; 6: FAAC magmatic foliation; 7: sedimentary cover; 8: alkaline rocks; 9: Rio Pardo Group; 10a: Itapetinga Complex; 10b: Itabuna-Salvador-Curaçá Orogen; 11: granite intrusion; 12: alkaline granites with more than 50\% dioritic enclaves; 13: syenitic intrusion; 14: syenite with high feldspathoid volume.

Figure 1. (A) Localization of the Alkaline Province of Southern Bahia (SBAP); (B) geological sketch map of SBAP, adapted from Rosa et al. (2007); (C) geological sketch map of the Floresta Azul Alkaline Complex (FAAC), adapted from Martins \& Santos (1997) and Rosa et al. (2003). 
of mixing between felsic and mafic magma, are common in granites. They are globular- or ellipsoid-shaped and were deformed by magmatic flow. They show fine-grained texture and alkali feldspar xenocrysts with evidence of corrosion by mafic magma. The mafic enclaves were dated at $688 \pm 2 \mathrm{Ma}$ (Rosa et al. 2003).

The fenite corresponds to modified granulitic country rock. It is coarse-grained and composed of saussuritized plagioclase, pyroxene, chloritized hornblende and biotite, besides newly formed ilmenite. Zircon and apatite occur with subhedral to euhedral forms. In this rock, metasomatic effects are evidenced by corroded quartz crystals, fresh alkali feldspar with amoeboid shape and late interstitial siderite, calcite and titanite.

\section{Metasomatism}

There is evidence of metasomatism and autometasomatism in the different massifs of SBAP (e.g., Cunha 2003, Rosa et al. 2007, Santos 2016). Alkaline fluids from the intrusions promoted fenitization of the metamorphic country rocks. In this process, the country rocks were modified and became syenite or nepheline syenite (Conceição et al. 2009). In the SBAP, the best examples of fenitization occur in the Itarantim Batholith, where approximately $45 \%$ of the outcrop area is composed of fenites (Conceição et al. 2009). However, in most SBAP massifs fenite occurs exclusively at the contact between the intrusion and the basement, as it is the case with FAAC.

Petrographical and geochemical data (Conceição et al. 2009, Santos 2016, Cunha 2003) allowed the interpretation that in the SBAP the composition of magmatic interstitial fluid had $\mathrm{Cl}, \mathrm{F}$ and $\mathrm{CO}_{2}$, leading to subsolidus crystallization of sodalite, cancrinite, fluorite and carbonate. $\mathrm{C}$ and $\mathrm{O}$ isotopic data from calcite crystals from nepheline syenite yielded mantellic values, and were interpreted by Rosa et al. (2007) as resulting from autometasomatism with no expressive input of crustal fluids.

\section{MATERIALS AND METHODS}

For this work, it was used thin sections of representative samples of syenitic and granitic intrusions, and from the fenite from FAAC. The samples were studied under the petrographic microscope Opton model TNP-09NT, equipped with transmitted and reflected light detection at the Laboratory of Microanalysis (CLGeo), at the Universidade Federal de Sergipe. After petrographic description, thin sections were reanalyzed under a back-scattered electron detector coupled to a Tescan Vega 3-LMU Scanning Electron Microscope at CLGeo Laboratory.
Monazite and apatite crystal chemical compositions were obtained by wavelength dispersive spectrometry (WDS) and by energy-dispersive spectrometry (EDS).

Electron probe analyses have been carried out in a JEOL JXA-8230 equipment coupled with five WDS spectrometers at Electron Microprobe Laboratory of Instituto de Geociências da Universidade de Brasília (IG-UnB). Peak counting time for all the analyzed elements was 10 seconds, and 5 seconds for background; the electron beam diameter was $1 \mu \mathrm{m}$. Due to the large number of examined elements, the analyses were conducted in two steps. The first one included F, Al, Si, Mn, Ti, Y, Ta, Hf, $\mathrm{Ca}, \mathrm{Fe}, \mathrm{Nb}, \mathrm{Zr}, \mathrm{P}$ and $\mathrm{W}$, with $15 \mathrm{kV}$ acceleration and current of $10 \mathrm{nA}$. The second group included $\mathrm{Na}, \mathrm{Eu}$, Gd, Sm, Tb, Er, Tm, Dy, Ho, Th, Sr, Ba, La, Ce, Nd, Pr, $\mathrm{Lu}, \mathrm{Yb}, \mathrm{Pb}, \mathrm{U}$ and $\mathrm{K}$, with $20 \mathrm{kV}$ voltage acceleration and current of $50 \mathrm{nA}$.

The spectral lines measurements were as follows: $\mathrm{K} \alpha(\mathrm{F}$, Al, Si, Mn, Ti, Y, Ca, Fe, P, Na, K), K $\beta$ (Ca), L $\alpha$ (Y, Eu, Gd, Tb, Er, Tm, Sr, Ba, La, Ce, Nd, Lu, Yb), L $\beta$ (Zr, Sm, P, Dy, Ho, Pr), M $\alpha$ (Ta, Th) and M $\beta$ (Hf, W, Pb, U). The following calibration standards were used: topaz $(\mathrm{F})$, microcline (Al, $\mathrm{K}$ and $\mathrm{Si}$ ), apatite (P and $\mathrm{Ca}$ ), $\mathrm{LiNbO}_{3}(\mathrm{Nb}), \mathrm{MnTiO}_{3}$ (Mn e Ti), $\mathrm{YFe}_{2} \mathrm{O}_{12}(\mathrm{Y}), \mathrm{LiTaO}_{3}(\mathrm{Ta})$, andradite $(\mathrm{Fe})$, baddeleyite $(\mathrm{Zr})$, albite $(\mathrm{Na})$, vanadinite $(\mathrm{Pb}), \mathrm{ThO}_{2}(\mathrm{Th}), \mathrm{SrSO}_{4}$ $(\mathrm{Sr}), \mathrm{UO}_{2}(\mathrm{U})$, and $\mathrm{BaSO}_{4}(\mathrm{Ba})$. Si-Ca-Al synthetic glass containing REE was used as standard, with the exception of $\mathrm{Ce}$, which was analyzed with a synthetic $\mathrm{CeO}_{2}$ standard.

The chemical composition of crystal points or sections $<5 \mu \mathrm{m}$ was obtained using EDS coupled to a Tescan SEM, Oxford Instruments model X-Act, from the CLGeo Lab, with resolution capability of $125 \mathrm{eV}$. The analytical settings used included a potential acceleration of $20 \mathrm{kV}$ and current of $17 \mathrm{nA}$, which generated electron beams with the diameter of $0.3 \mu \mathrm{m}$.

The average counting time was 60 seconds. EDS calibration was made routinely with $\mathrm{Cu}$ energy. To check the accuracy and reproducibility of the data, international standards Astimex (monazite) and Cameca (fluorapatite and chlorapatite) were analyzed. The results can be seen in Table 1 . The software used for obtaining the chemical compositions was AZtecEnergy, Quant routine, by Oxford Instruments, which employs the ZAF model for matrix corrections. In order to avoid problems of element energy superposition, the energy spectra obtained was individually analyzed (e.g., Newbury 2009). We checked for the presence of false peaks and energy interferences. In either case, the interference was manually removed. The confidence interval obtained from the EDS is $>90 \%$ for elements whose content in weight is higher than $10 \%$. For values $<5 \%$ in weight, the confidence factor ranges between 70 and $80 \%$. 


\section{RESULTS}

Monazite has been found in three samples of FAAC rocks: nepheline syenite, granite and fenite (fenitized granulite). Representative analyses of the monazite crystals are presented in Table 2 .

The standard formula for monazite is (REE) $\mathrm{PO}_{4}$. After calculating its structural formula based on four oxygen atoms (Tab. 2), cation distribution was then performed: the tetrahedral position has been filled with $\mathrm{P}^{3+}, \mathrm{Si}^{4+}$ and $\mathrm{Al}^{3+}$ up to a maximum of one atom per formula unit (apfu). The dodecahedral position has been filled with $\mathrm{REE}\left(\mathrm{La}^{3+}, \mathrm{Ce}^{3+}, \mathrm{Nd}^{3+}\right.$, $\mathrm{Pr}^{3+}, \mathrm{Sm}^{3+}, \mathrm{Eu}^{3+}, \mathrm{Gd}^{3+}, \mathrm{Tb}^{3+}, \mathrm{Dy}^{3+}, \mathrm{Ho}^{3+}$ and $\left.\mathrm{Tm}^{3+}\right)$ and with other cations (e.g., $\mathrm{Na}^{+}, \mathrm{Ca}^{2+}, \mathrm{Sr}^{2+}, \mathrm{Fe}^{2+}, \mathrm{Y}^{3+}, \mathrm{W}^{3+}, \mathrm{U}^{4+}, \mathrm{Th}^{4+}$, $\left.\mathrm{Hf}^{4+}, \mathrm{Zr}^{4+}, \mathrm{Ti}^{4+}\right)$ up to 1 apfu.

In the syenitic rocks monazite crystals are anhedral with size ranging from 1 to $35 \mu \mathrm{m}$, predominated those with $10 \mu \mathrm{m}$. Monazite occurs closely associated with apatite and ancylite $(\mathrm{Sr}, \mathrm{Ca}, \mathrm{Ce}, \mathrm{La})\left(\mathrm{CO}_{3}\right)_{2}(\mathrm{OH}) \mathrm{H}_{2} \mathrm{O}$. It either can surround or be surrounded by both apatite or ancylite (Fig. 2). These minerals occupy interstitial spaces between microcline, albite and nepheline. They also can be found associated with sodalite and cancrinite and occasionally in microfractures. Apatite and monazite crystals are chemically homogeneous. Monazite is more abundant in sodalite- and cancrinite-rich syenite. In the analyzed monazite crystals, the amounts of the REE oxides ranged from 68.1 to $72.7 \%$, with prevalence of $\mathrm{Ce}_{2} \mathrm{O}_{3}(30-37.5 \%)$ and $\mathrm{La}_{2} \mathrm{O}_{3}(20.4-33.8 \%)$. $\mathrm{ThO}_{2}$ contents range from 0.46 to $1.3 \%$ (Tab. 2).

In the granitic rocks, monazite fills pore spaces and fractures in apatite (Fig. 3). Crystals are anhedral with sizes ranging between $<1$ and $100 \mu \mathrm{m}$, with prevalence of crystals $<1 \mu \mathrm{m}$, the largest ones occurring along apatite rims. Occasionally, anhedral to subhedral xenotime crystals with size up to $5 \mu \mathrm{m}$ occur associated with monazite. Apatite contains inclusions of magnetite, ilmenite and fractures filled by calcite (Fig. 3A and 3B). Back-scatter detector (BSE) images show that apatite acquires a darker gray color where monazite crystals are present, and this dark grey apatite has a chemical composition which is closer to stoichiometric fluorapatite (Tab. 3). Lighter grey areas in apatite are devoid of monazite crystals and are richer in REE + Si (Fig. 3B). The sum of REE oxides in monazite ranges from 70.1 to $71.6 \%$, with the prevalence of $\mathrm{Ce}_{2} \mathrm{O}_{3}(33.7-36.7 \%)$ and $\mathrm{La}_{2} \mathrm{O}_{3}(14.07-22.5 \%)$. The maximum content of $\mathrm{ThO}_{2}$ was $0.6 \%$ (Tab. 2).

Monazite is occasionally observed in the fenite. Crystals are elongated and occur as inclusions in subhedral or euhedral apatite (Fig. 4). They range from 1 to $10 \mu \mathrm{m}$ wide, $5 \mu \mathrm{m}$ being the most frequent. Monazite orientation is parallel to apatite crystallographic c-axis. Unlike apatite found in the granites, in fenite apatite crystals which host monazite inclusions are homogeneous, devoid of pores or compositional variations visible in BSE images. Regarding compositionally, REE contents are lower than in other rock types from the

Table 1. Comparison between chemical compositions of standards (monazite Astimex) and chlorapatite and fluorapatite (Cameca) and analysis of these standards obtained by EDS (this study). Table shows difference module (\#) between the given standard values and measured figures.

\begin{tabular}{l|c|c|c|c|c|c|c|c|c}
\hline & \multicolumn{3}{|c|}{ Monazite } & \multicolumn{3}{c|}{ Apatite-Cl } & \multicolumn{3}{c}{ Apatite-F } \\
\cline { 2 - 9 } & Standard & EDS & $\#$ & Standard & EDS & $\#$ & Standard & EDS & $\#$ \\
\hline $\mathrm{P}_{2} \mathrm{O}_{5}$ & 27.73 & 28.45 & 0.72 & 40.88 & 40.10 & 0.78 & 42.22 & 41.60 & 0.62 \\
\hline $\mathrm{SiO}_{2}$ & & 1.20 & 1.20 & & & & & & \\
\hline $\mathrm{La}_{2} \mathrm{O}_{3}$ & 15.13 & 17.30 & 2.17 & & & & & & \\
\hline $\mathrm{Ce}_{2} \mathrm{O}_{3}$ & 36.08 & 33.85 & 2.23 & & & & & & \\
\hline $\mathrm{Pr}_{2} \mathrm{O}_{3}$ & 4.92 & 3.30 & 1.62 & & & & & & \\
\hline $\mathrm{Nd}_{2} \mathrm{O}_{3}$ & 10.15 & 10.30 & 0.15 & & & & & & \\
\hline $\mathrm{Sm}_{2} \mathrm{O}_{3}$ & & 1.10 & 1.10 & & & & & & \\
\hline $\mathrm{CaO}$ & 0.56 & 0.50 & 0.06 & 53.84 & 53.20 & 0.64 & 55.60 & 54.60 & 1.00 \\
\hline $\mathrm{ThO}_{2}$ & 4.32 & 3.80 & 0.52 & & & & & & \\
\hline $\mathrm{Cl}$ & & & & 6.81 & 6.60 & 0.21 & & & \\
\hline $\mathrm{F}$ & & & & & & & 3.67 & 3.70 & 0.03 \\
\hline $\mathrm{Total}$ & 98.89 & 99.80 & & 101.53 & 99.90 & & 101.49 & 99.90 & \\
\hline
\end{tabular}

EDS: energy-dispersive spectrometry. 
Jailson Júnior Alves Santos et al.

Table 2. Representative sample analysis of monazite crystals and structural formula cation distribution in Floresta Azul Alkaline Complex (FAAC) rocks.

\begin{tabular}{|c|c|c|c|c|c|c|c|c|c|c|c|}
\hline \multirow{3}{*}{$\begin{array}{c}\text { Rock } \\
\text { Method } \\
\text { Analyse }\end{array}$} & \multicolumn{4}{|c|}{ Syenite } & \multicolumn{4}{|c|}{ Granite } & \multirow{2}{*}{\multicolumn{3}{|c|}{$\begin{array}{c}\text { Fenite } \\
\text { EDS }\end{array}$}} \\
\hline & \multicolumn{2}{|c|}{ WDS } & \multicolumn{2}{|c|}{ EDS } & \multicolumn{2}{|c|}{ WDS } & \multicolumn{2}{|c|}{ EDS } & & & \\
\hline & 1 & 2 & 3 & 4 & 5 & 6 & 7 & 8 & 9 & 10 & 11 \\
\hline $\mathrm{P}_{2} \mathrm{O}_{5}$ & 22.87 & 24.61 & 30.50 & 29.80 & 20.84 & 22.39 & 29.10 & 28.30 & 28.30 & 28.20 & 28.70 \\
\hline $\mathrm{SiO}_{2}$ & 0.09 & 3.01 & & & 1.85 & 0.05 & & & 0.60 & 0.40 & 0.50 \\
\hline $\mathrm{Al}_{2} \mathrm{O}_{3}$ & 0.02 & 1.37 & & & 0.04 & & & & & & \\
\hline $\mathrm{La}_{2} \mathrm{O}_{3}$ & 26.17 & 23.25 & 33.80 & 20.40 & 15.98 & 14.07 & 16.10 & 22.50 & 27.80 & 27.90 & 27.60 \\
\hline $\mathrm{Ce}_{2} \mathrm{O}_{3}$ & 37.55 & 37.85 & 30.60 & 35.40 & 36.67 & 34.31 & 34.70 & 33.70 & 30.70 & 31.00 & 31.10 \\
\hline $\mathrm{Pr}_{2} \mathrm{O}_{3}$ & 2.27 & 2.04 & & 4.10 & 3.22 & 3.74 & 3.80 & 3.80 & 2.90 & 3.10 & 2.40 \\
\hline $\mathrm{Nd}_{2} \mathrm{O}_{3}$ & 5.95 & 5.11 & 3.70 & 8.10 & 12.68 & 15.64 & 13.00 & 8.70 & 5.80 & 4.90 & 4.90 \\
\hline $\mathrm{Sm}_{2} \mathrm{O}_{3}$ & 0.29 & 0.32 & & 1.20 & 1.38 & 2.21 & 1.40 & 1.00 & 0.70 & 0.80 & 0.30 \\
\hline $\mathrm{Eu}_{2} \mathrm{O}_{3}$ & 0.50 & 0.35 & & & 0.83 & 1.08 & & & & & \\
\hline $\mathrm{Gd}_{2} \mathrm{O}_{3}$ & & & & 0.50 & 0.05 & 0.47 & 1.10 & 0.50 & & 0.70 & \\
\hline $\mathrm{Tb}_{2} \mathrm{O}_{3}$ & 0.01 & 0.03 & & & & & & & & & 0.80 \\
\hline $\mathrm{Dy}_{2} \mathrm{O}_{3}$ & & & & 0.60 & 0.05 & & & 0.60 & 0.90 & 0.80 & 0.40 \\
\hline $\mathrm{Ho}_{2} \mathrm{O}_{3}$ & & 0.03 & & & & & & & 0.30 & & \\
\hline $\mathrm{Tm}_{2} \mathrm{O}_{3}$ & & & & & & 0.03 & & & & & 0.80 \\
\hline $\mathrm{Y}_{2} \mathrm{O}_{3}$ & & 0.02 & & & 0.13 & 0.01 & & & & & \\
\hline $\mathrm{CaO}$ & 0.47 & 0.05 & & & 0.47 & & & 0.40 & 2.10 & 2.30 & 2.50 \\
\hline $\mathrm{FeO}$ & & & & & 0.20 & 0.05 & & & & & \\
\hline $\mathrm{TiO}_{2}$ & 0.10 & & & & 0.06 & 0.19 & & & & & \\
\hline $\mathrm{ZrO}_{2}$ & 0.56 & 0.51 & & & 0.72 & 0.43 & & & & & \\
\hline $\mathrm{WO}_{3}$ & & 0.20 & & & 0.28 & & & & & & \\
\hline $\mathrm{HfO}_{2}$ & & & & & 0.62 & & & & & & \\
\hline $\mathrm{ThO}_{2}$ & 0.15 & 0.46 & 1.30 & & 0.43 & 0.02 & 0.60 & 0.50 & & & \\
\hline $\mathrm{UO}_{2}$ & & & & & & & 0.20 & & & & \\
\hline $\mathrm{F}$ & 1.41 & 0.92 & & & 1.19 & 1.17 & & & & & \\
\hline Total & 98.39 & 100.12 & 99.90 & 100.10 & 97.67 & 95.88 & 100.00 & 100.00 & 100.10 & 100.10 & 100.00 \\
\hline$\sum R E E$ & 72.73 & 68.99 & 68.10 & 70.30 & 70.99 & 71.57 & 70.10 & 70.80 & 69.10 & 69.20 & 68.30 \\
\hline \multicolumn{12}{|c|}{ Structural formula with base in four oxygens } \\
\hline $\mathrm{P}$ & 0.817 & 0.812 & 1.006 & 0.994 & 0.758 & 0.827 & 0.983 & 0.965 & 0.948 & 0.947 & 0.958 \\
\hline $\mathrm{Si}$ & 0.004 & 0.117 & & & 0.079 & 0.002 & & & 0.024 & 0.016 & 0.020 \\
\hline $\mathrm{Al}$ & 0.001 & 0.063 & & & 0.002 & & & & & & \\
\hline La & 0.407 & 0.334 & 0.486 & 0.296 & 0.253 & 0.226 & 0.237 & 0.334 & 0.406 & 0.408 & 0.401 \\
\hline $\mathrm{Ce}$ & 0.580 & 0.540 & 0.437 & 0.511 & 0.577 & 0.548 & 0.507 & 0.497 & 0.445 & 0.450 & 0.449 \\
\hline $\operatorname{Pr}$ & 0.035 & 0.029 & & 0.059 & 0.050 & 0.060 & 0.055 & 0.056 & 0.042 & 0.045 & 0.034 \\
\hline $\mathrm{Nd}$ & 0.090 & 0.071 & 0.052 & 0.114 & 0.195 & 0.244 & 0.185 & 0.125 & 0.082 & 0.069 & 0.069 \\
\hline
\end{tabular}


Table 2. Continuation.

\begin{tabular}{|c|c|c|c|c|c|c|c|c|c|c|c|}
\hline \multicolumn{12}{|c|}{ Structural formula with base in four oxygens } \\
\hline Sm & 0.004 & 0.004 & & 0.016 & 0.020 & 0.033 & 0.019 & 0.014 & 0.010 & 0.011 & 0.004 \\
\hline $\mathrm{Eu}$ & 0.015 & 0.010 & & & 0.025 & 0.034 & & & & & \\
\hline Gd & & & & 0.007 & 0.001 & 0.007 & 0.015 & 0.007 & & 0.009 & \\
\hline Dy & & & & 0.008 & 0.001 & & & 0.008 & 0.011 & 0.010 & 0.005 \\
\hline Ho & & & & & & & & & 0.004 & & \\
\hline $\operatorname{Tm}$ & & & & & & & & & & & 0.010 \\
\hline $\mathrm{Y}$ & & & & & 0.003 & & & & & & \\
\hline $\mathrm{Ca}$ & 0.021 & 0.002 & & & 0.022 & & & 0.017 & 0.089 & 0.098 & 0.106 \\
\hline $\mathrm{Fe}$ & & & & & 0.007 & 0.002 & & & & & \\
\hline $\mathrm{Ti}$ & 0.003 & & & & 0.002 & 0.006 & & & & & \\
\hline $\mathrm{Zr}$ & 0.011 & 0.010 & & & 0.015 & 0.009 & & & & & \\
\hline W & & 0.002 & & & 0.003 & & & & & & \\
\hline $\mathrm{Hf}$ & & & & & 0.008 & & & & & & \\
\hline Th & 0.001 & 0.004 & 0.012 & & 0.004 & & 0.005 & 0.005 & & & \\
\hline $\mathrm{U}$ & & & & & & & 0.002 & & & & \\
\hline Total & 1.989 & 1.999 & 1.992 & 2.004 & 2.025 & 1.999 & 2.009 & 2.027 & 2.060 & 2.063 & 2.056 \\
\hline
\end{tabular}

WDS: wavelength dispersive spectrometry; EDS: energy-dispersive spectrometry.
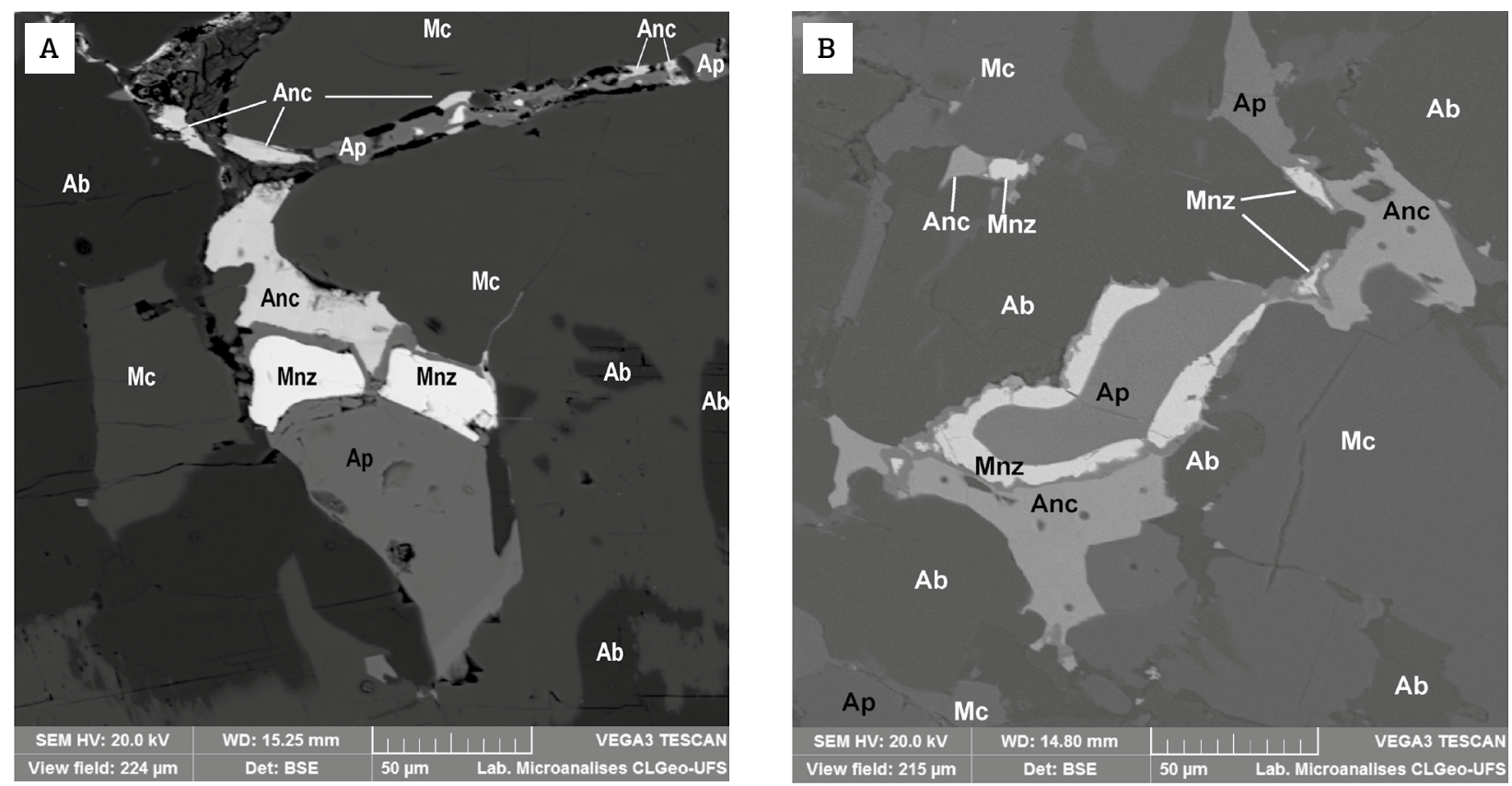

Figure 2. Back-scattered electron image showing texture of monazite, apatite and ancylite in nepheline syenite from the Floresta Azul Alkaline Complex (FAAC). (A) Apatite (Ap) surrounding monazite crystals (Mnz) and in contact with ancyilite (Anc); these minerals fill interstitial spaces and fractures in microcline $(\mathrm{Mc})$ and albite $(\mathrm{Ab})$. (B) Apatite rimmed by monazite and ancylite, with occurrences of monazite surrounded by apatite and ancylite. 
FAAC, ranging from 68.3 to $69.1 \%$. The most abundant REE are $\mathrm{Ce}_{2} \mathrm{O}_{3}(30.7-31.1 \%)$ and $\mathrm{La}_{2} \mathrm{O}_{3}(27.6-26.9 \%)$.

The monazite from this study corresponds to a relatively uniform population of huttonite- and cheralite-poor crystals (Linthout 2007) (Fig. 5A). Monazite-(Ce) is common in all of the studied rock types, except for the syenites, which have monazite-(La) (Fig. 5B).

Some authors (e.g., Fleischer \& Altschuler 1969, Rapp $\&$ Watson 1986) correlate the REE abundances and ratios to carbonatitic, granitic and hydrothermal rocks. In the $\mathrm{La} / \mathrm{Nd}$ versus $[\mathrm{La}+\mathrm{Ce}+\mathrm{Pr}]$ diagram (Fig. 6), it is possible to see a pronounced La enrichment in crystals from the syenitic rocks, with most of analyses occurred in the upper part of the space attributed to monazite associated with carbonaceous magmatism or hydrothermal processes. Monazite of the granitic rocks shows the lowest $\mathrm{La} / \mathrm{Nd}$ rates (Fig. 6). The $\mathrm{La} / \mathrm{Nd}$ rates for the fenite's crystals are similar to those assigned to the FAAC granite and syenite (Fig. 6).

\section{DISCUSSION}

In the rocks of the FAAC, monazite occurs in three different arrangements: interstitial crystals in nepheline syenite; anhedral crystals included in apatite crystals with REE +
Si-poor areas, in granite; and subhedral elongated crystals included in fenite's apatite.

The association between monazite and apatite crystals is common in a number of rock types and has been related to either magmatic crystallization (Wark \& Miller 1993) or to processes involving apatite reactions with fluids (Harlov 2015).

In the nepheline syenites, the interstices between alkali feldspar and nepheline are filled witch cancrinite, sodalite, apatite, monazite, ancylite and calcite. Apatite is bordered by monazite and ancylite and viceversa, pointing out to concomitant crystallization of these minerals. The presence of sodalite, ancylite, cancrinite and calcite as interstitial phases in these rocks indicates formation during a late magmatic stage in the presence of $\mathrm{Cl}$ - and $\mathrm{CO}_{2}$ - rich fluid phase. According to Alderton et al. (1980), the presence of a volatile phase involving $\mathrm{Cl}, \mathrm{CO}_{2}$ and $\mathrm{F}$ in alkaline complexes accounts for REE transportation and for the late crystallization of accessory phases rich in those elements. For example, in the nepheline syenites of Alkaline Province of Chilwa, Africa, monazite occurs in association with fluorecite and bastnäesite (Platt et al. 1987), whereas in a nepheline syenite from British Columbia, Canada (Pell 1994), monazite occurs in association with allanite, cheralite, apatite and pyrochlore.
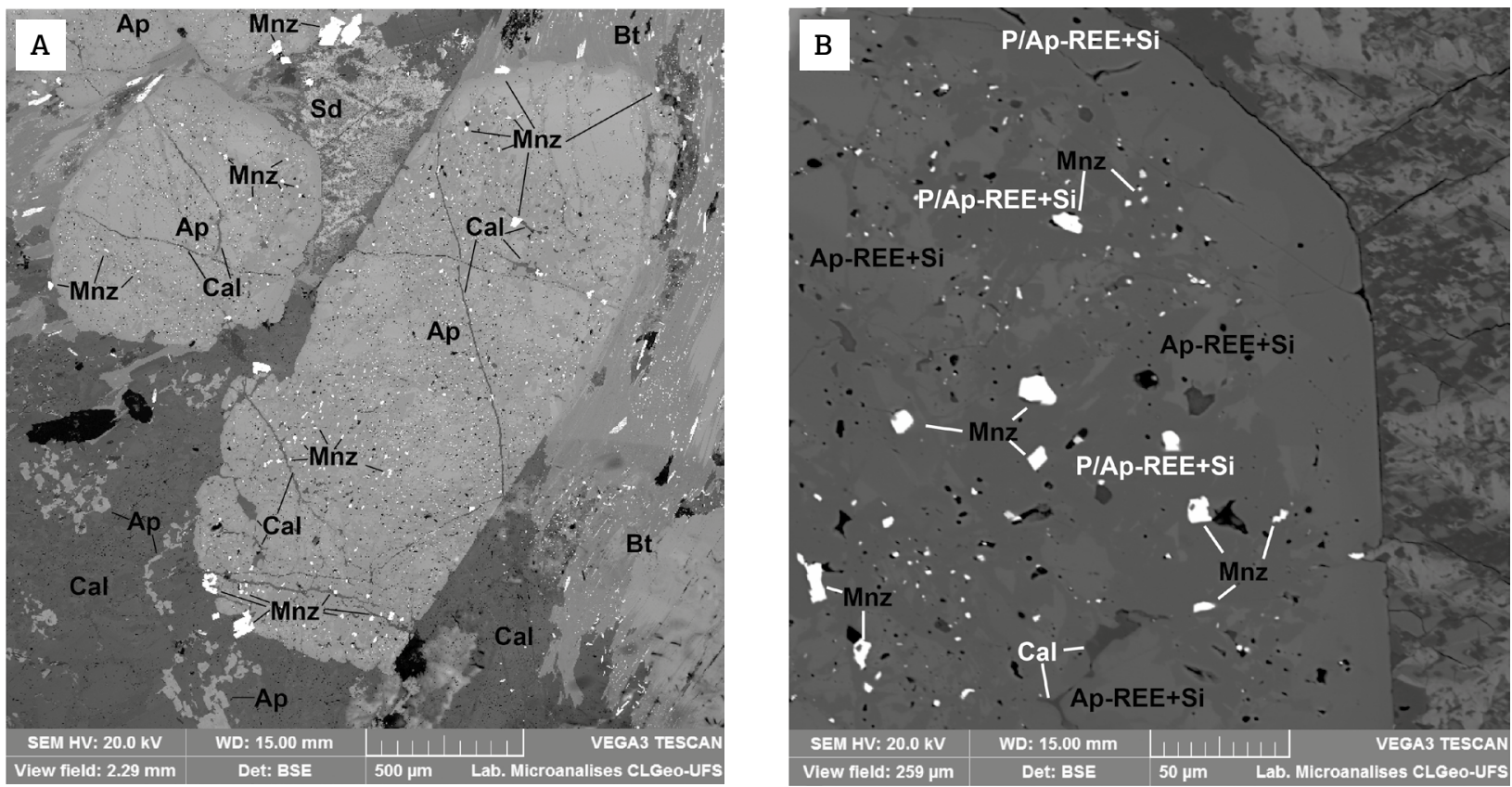

Figure 3. Back-scattered electron image showing texture of monazite and apatite in granite from the Floresta Azul Alkaline Complex (FAAC). (A) Subhedral apatite (Ap) crystals in contact with calcite (Cal), siderite (Sd) and biotite (Bt). Apatite contains many monazite (Mnz) inclusions in pores and fractures. (B) Detail of apatite in contact with calcite (Cal) and siderite (Sd) with disseminated monazite (white) and empty pores (black), fractures filled by calcite. Lighter areas have higher content of REE + Si (Ap-REE + Si), while darker areas are poor in REE $+\mathrm{Si}(\mathrm{P} / \mathrm{Ap}-\mathrm{REE}+\mathrm{Si})$. 
The presence of apatite crystals with REE- and Si- depleted areas associated with monazite in the FAAC granites (Tab. 3) is interpreted as the result of fluid percolation (Harlov \& Förster 2002, 2003, Harlov et al. 2002, 2005, Harlov 2015). Experimental studies carried out by Harlov et al. (2005) on the interactions between apatite crystals and $\mathrm{HCl}$ and $\mathrm{H}_{2} \mathrm{SO}_{4}$ solutions in temperatures ranging from $300^{\circ} \mathrm{C}$ to $900^{\circ} \mathrm{C}$ and pressures between $500-1,000 \mathrm{Mpa}$ show that monazite and xenotime are formed from apatite, and are located in portions of REE-poor apatite crystals. According

Table 3. In situ EDS chemical analysis of partially leached apatite crystals, in samples of the granitic intrusion, making it possible to see different stages of interaction with the late fluids.

\begin{tabular}{|c|c|c|c|c|c|c|c|c|c|}
\hline \multirow{2}{*}{ Apatite } & \multicolumn{3}{|c|}{ Without change } & \multicolumn{3}{|c|}{ Partially leached } & \multicolumn{3}{|c|}{ Leached } \\
\hline & 1 & 2 & 3 & 4 & 5 & 6 & 7 & 8 & 9 \\
\hline $\mathrm{P}_{2} \mathrm{O}_{5}$ & 39.9 & 40.3 & 40.4 & 40.8 & 41.1 & 40.7 & 41.2 & 41.2 & 41.2 \\
\hline $\mathrm{SiO}_{2}$ & 0.9 & 0.7 & 0.6 & 0.2 & & 0.4 & & & \\
\hline $\mathrm{La}_{2} \mathrm{O}_{3}$ & 0.5 & 0.5 & 0.3 & 0.1 & & 0.2 & & & \\
\hline $\mathrm{Ce}_{2} \mathrm{O}_{3}$ & 1.3 & 1.1 & 0.9 & 0.3 & 0.1 & 0.6 & & & \\
\hline $\mathrm{Pr}_{2} \mathrm{O}_{3}$ & 0.3 & 0.2 & 0.2 & 0.1 & 0.1 & 0.1 & & & \\
\hline $\mathrm{Nd}_{2} \mathrm{O}_{3}$ & 0.5 & 0.5 & 0.3 & 0.1 & 0.3 & 0.2 & & & \\
\hline $\mathrm{Sm}_{2} \mathrm{O}_{3}$ & 0.1 & & 0.1 & & & & & & \\
\hline $\mathrm{Eu}_{2} \mathrm{O}_{3}$ & 0.3 & 0.2 & 0.2 & & 0.2 & & & & \\
\hline $\mathrm{Tm}_{2} \mathrm{O}_{3}$ & & & 0.2 & & & & & & \\
\hline $\mathrm{CaO}$ & 52.6 & 53 & 53.1 & 53.9 & 54.3 & 53.7 & 54.6 & 54.5 & 54.6 \\
\hline $\mathrm{Na}_{2} \mathrm{O}$ & 0.2 & 0.2 & 0.2 & 0.2 & 0.1 & 0.2 & & & \\
\hline $\mathrm{Cl}$ & 0.3 & 0.5 & 0.5 & 0.2 & 0.2 & 0.3 & 0.1 & 0.1 & \\
\hline $\mathrm{F}$ & 3.2 & 2.9 & 3 & 4.4 & 3.6 & 3.6 & 4.2 & 4.2 & 4.1 \\
\hline $\mathrm{H}_{2} \mathrm{O}^{*}$ & 0.91 & 0.94 & 0.92 & 0.68 & 0.87 & 0.84 & 0.76 & 0.76 & 0.81 \\
\hline $\mathrm{O}=\mathrm{F} . \mathrm{Cl}$ & -0.72 & -0.70 & -0.72 & -0.94 & -0.78 & -0.80 & -0.88 & -0.88 & -0.83 \\
\hline Total & 100.29 & 100.34 & 100.19 & 100.04 & 100.09 & 100.04 & 99.99 & 99.88 & 99.88 \\
\hline \multicolumn{10}{|c|}{ Structural formula with base in 25 oxygens } \\
\hline$P$ & 5.891 & 5.918 & 5.930 & 5.963 & 5.983 & 5.946 & 5.985 & 5.989 & 5.985 \\
\hline $\mathrm{Si}$ & 0.157 & 0.121 & 0.104 & 0.035 & & 0.069 & & & \\
\hline $\mathrm{Ce}$ & 0.028 & 0.023 & 0.019 & 0.006 & 0.002 & 0.013 & & & \\
\hline $\mathrm{La}$ & 0.011 & 0.011 & 0.006 & 0.002 & & 0.004 & & & \\
\hline $\operatorname{Pr}$ & 0.006 & 0.004 & 0.004 & 0.002 & 0.002 & 0.002 & & & \\
\hline $\mathrm{Nd}$ & 0.010 & 0.010 & 0.006 & 0.002 & 0.006 & 0.004 & & & \\
\hline $\mathrm{Sm}$ & 0.002 & & 0.002 & & & & & & \\
\hline $\mathrm{Eu}$ & 0.006 & 0.004 & 0.004 & & 0.004 & & & & \\
\hline $\mathrm{Tm}$ & & & 0.004 & & & & & & \\
\hline $\mathrm{Ca}$ & 9.829 & 9.850 & 9.865 & 9.970 & 10.004 & 9.929 & 10.038 & 10.027 & 10.038 \\
\hline $\mathrm{Na}$ & 0.068 & 0.067 & 0.067 & 0.067 & 0.033 & 0.067 & & & \\
\hline Total & 16.008 & 16.009 & 16.011 & 16.048 & 16.035 & 16.034 & 16.023 & 16.016 & 16.023 \\
\hline
\end{tabular}

EDS: energy-dispersive spectrometry; *calculated by stoichiometry. 
to these authors, in the presence of $\mathrm{HCl}$ fluid, the formation of monazite crystals with size ranging from $<1-10 \mu \mathrm{m}$ was favored. In intermediate temperatures $\left(\approx 600^{\circ} \mathrm{C}\right)$, there was an increase in the number of monazite inclusions, but with size lower than $1 \mu \mathrm{m}$. On the other hand, the interaction between apatite crystals and the $\mathrm{H}_{2} \mathrm{SO}_{4}$ solution formed smaller monazite crystals $(<2 \mu \mathrm{m})$ and was considered to be less effective, needing more reaction time, higher temperature and higher $\mathrm{H}_{2} \mathrm{SO}_{4}$ concentration.

The fact that apatite crystals from the FAAC granites show areas poor in REE + Si associated with monazite crystals as opposed to the non-depleted apatite areas without
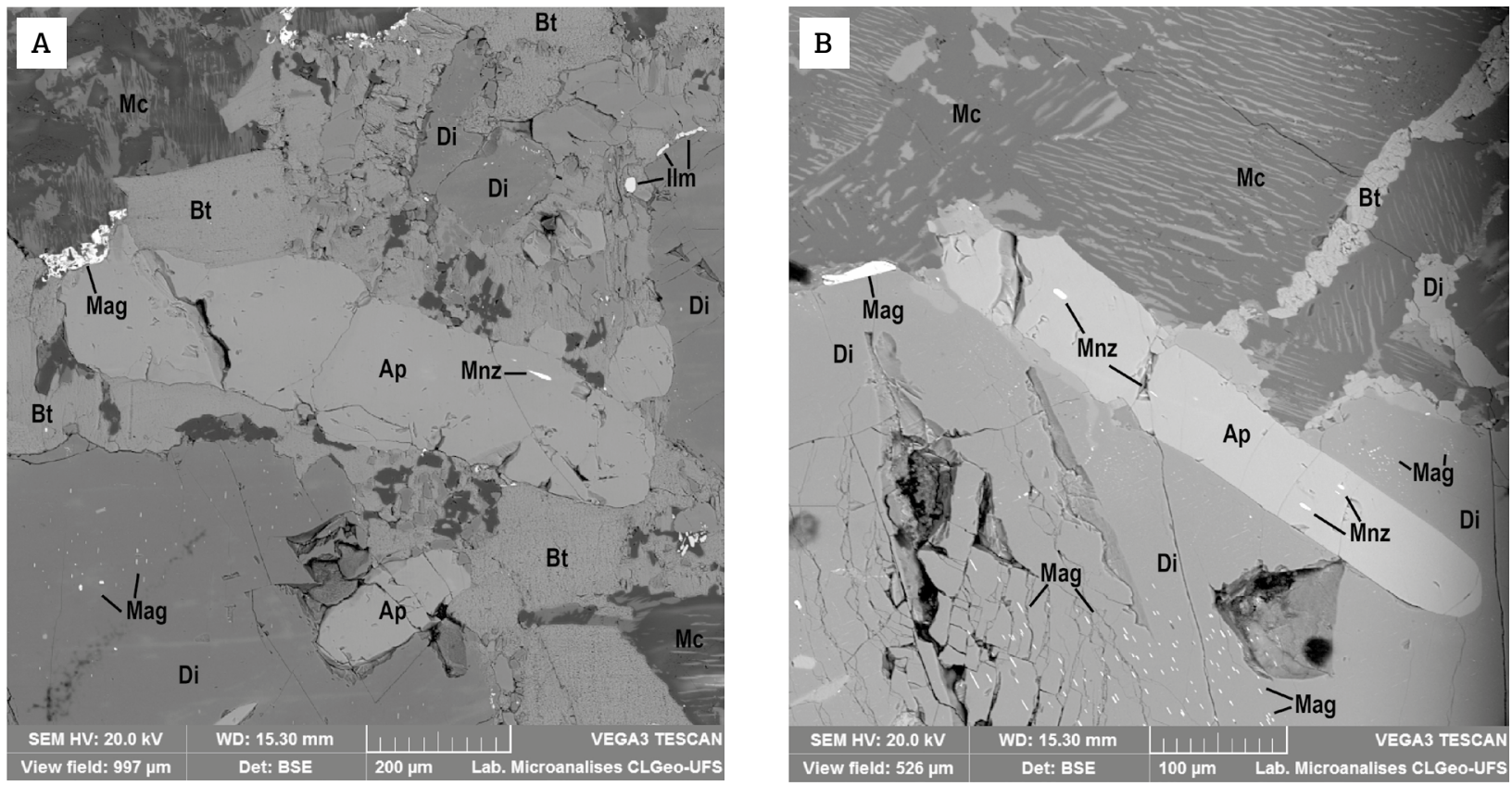

Figure 4. Back-scattered electron image showing texture of apatite and monazite crystals in the fenite from the Floresta Azul Alkaline Complex (FAAC). (A and B) Apatite subhedral crystals and elongated monazite crystals parallel to apatite's c-axis. Microcline $(\mathrm{Mc})$, biotite $(\mathrm{Bt})$ and diopside $(\mathrm{Di})$ show exsolved magnetite (Mag) and ilmenite (Ilm) crystals.

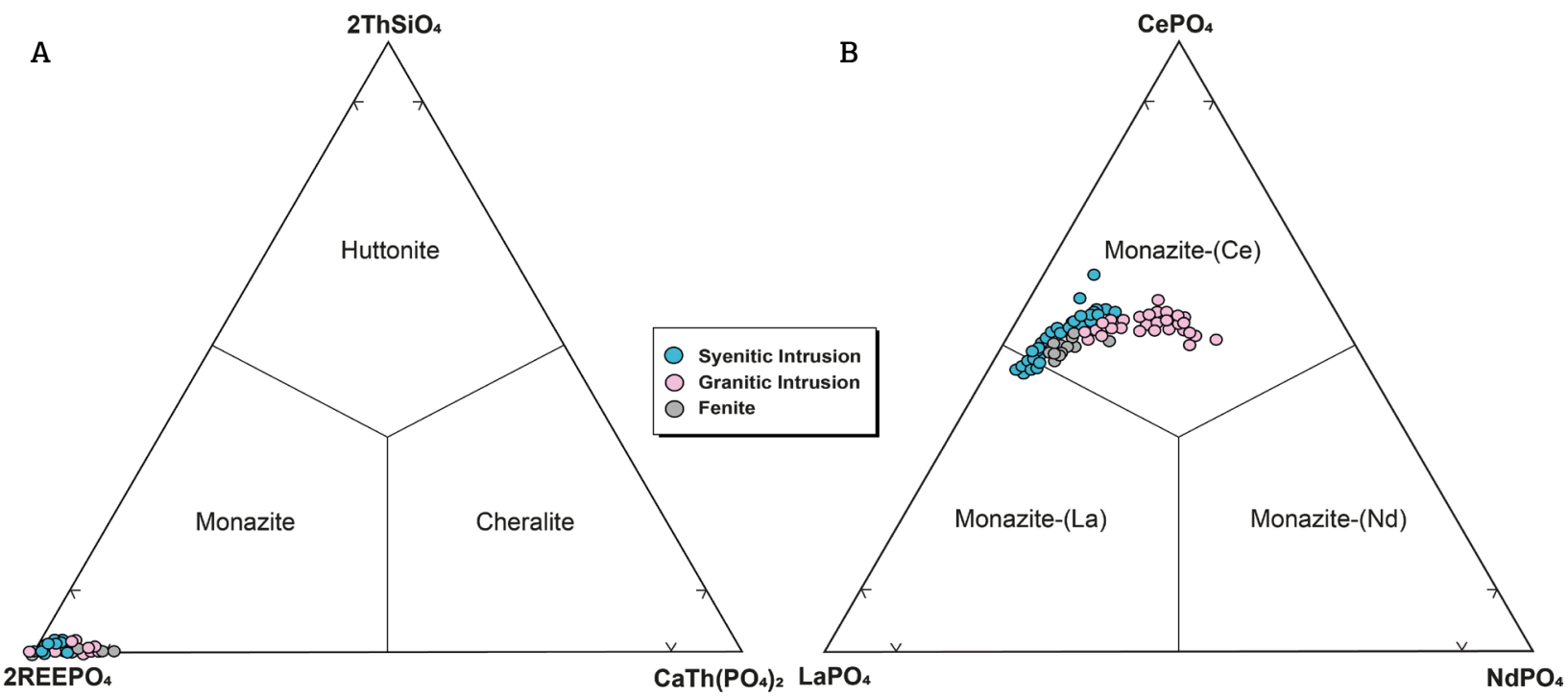

Figure 5. Monazite classification diagrams. (A) Classification proposed by Linthout (2007) for the monazite group, based on the molecular contents of $2 \mathrm{ThSiO}_{4}$ (Huttonite)-2CePO${ }_{4}\left(\right.$ Monazite)-CaTh$\left(\mathrm{PO}_{4}\right)_{2}$ (Cheralite). (B) Classification of monazite using Nickel's (1992) 50\% Rule, based on molecular contents of Monazite-(Ce) $\left(\mathrm{CePO}_{4}\right)-\mathrm{Monazite}^{-}$ (La) $\left(\mathrm{LaPO}_{4}\right)-$ Monazite-(Nd) $\left(\mathrm{NdPO}_{4}\right)$. 
monazite inclusions (Fig. 7) is interpreted in this study as resulting from the interaction with fluids leaching REE from apatite, and coeval formation of monazite in pores and fractures. According to Rønsbo (1989), two main substitutions control the incorporation or the removal of REE in the apatite: $\mathrm{REE}^{3+}+\mathrm{Si}^{4+}=\mathrm{Ca}^{2+}+\mathrm{P}^{5+}($ Fig. $8 \mathrm{~A})$ and $\mathrm{REE}^{3+}+\mathrm{Na}^{+}$ $=2 \mathrm{Ca}^{2+}$. The first substitution probably operated to generate the chemical features of the studied crystals, with good

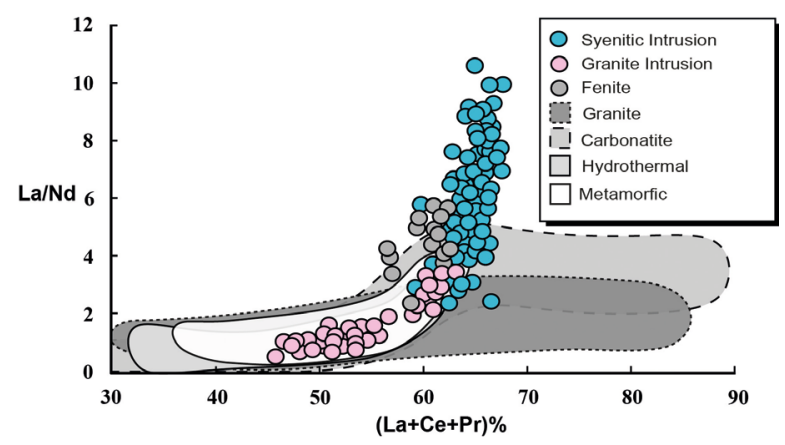

Figure 6. Correlation diagram $(\mathrm{La} / \mathrm{Nd})$ versus $(\mathrm{La}+\mathrm{Ce}$ + Pr) (Raap \& Watson 1986) applied to Floresta Azul Alkaline Complex (FAAC) monazite. Fields with the composition of granite (Rapp \& Watson 1986, Foerster 1998, Zhu \& O’Nions 1999, Teixeira \& Botelho 2002); carbonatite (Chakhmouradian \& Mitchell 1998, Toledo et al. 2004, Kim et al. 2005); hydrothermal (Zhu \& O'Nions 1999, Teixeira \& Botelho 2002); and metamorphic (Zhu \& O’Nions 1999, Finger \& Krenn 2007) monazite. linear correlation $\left(r^{2}=0,9738\right.$, Fig. $\left.8 A\right)$, whereas the effects of the second one were not observed in the studied rocks.

The REE-poor areas in the apatite crystals are Cl-depleted and F-rich. In apatite, the exchange between halogens and hydroxyl $(\mathrm{F}, \mathrm{Cl}$ and $\mathrm{OH})$ is usual and reflects the abundance of either $\mathrm{F}, \mathrm{Cl}$ or $\mathrm{OH}$ in the magma/fluid at the moment of crystallization or alteration (Schettler et al. 2011). In the studied rocks, only fluorapatite occurs, locally with low $\mathrm{Cl}$ contents $(<0.6 \%)$. Along with leaching, there is increase in $\mathrm{F}$, indicating the existence of the $\mathrm{F}-\mathrm{Cl}$ substitution in the studied crystals. Experimental data (Pan \& Fleet 2002) indicate the replacement of $\left(\mathrm{REE}^{3+}+\mathrm{O}^{2-}\right)$ for $\left(\mathrm{Ca}^{2+}+\mathrm{F}^{1-}\right)$ in apatite. The good linear correlation $\left(\mathrm{r}^{2}=0.9873\right)$ identified in the studied crystals implies that this substitution was operative in the studied rocks (Fig 8B). The presence of calcite in apatite fractures continuous with the REE- and Si-leached areas probably reflects the trajectory of a $\mathrm{CO}_{2}$-rich fluid. The presence of pores and fractures in the REE-poor areas of apatite crystals reinforces the hypothesis of crystal dissolution, enabling fluid percolation.

The formation of monazite crystals parallel to the c-axis of the apatite crystals, like the ones occurring in fenites from FAAC, is reported in the literature as a common feature in rocks exposed to either metamorphism or metasomatism (Finger \& Krenn 2007, Harlov 2015, Budzyn et al. 2010). Most probably, the low content of REE found in the apatite of these rocks accounts for the low frequency of monazite.
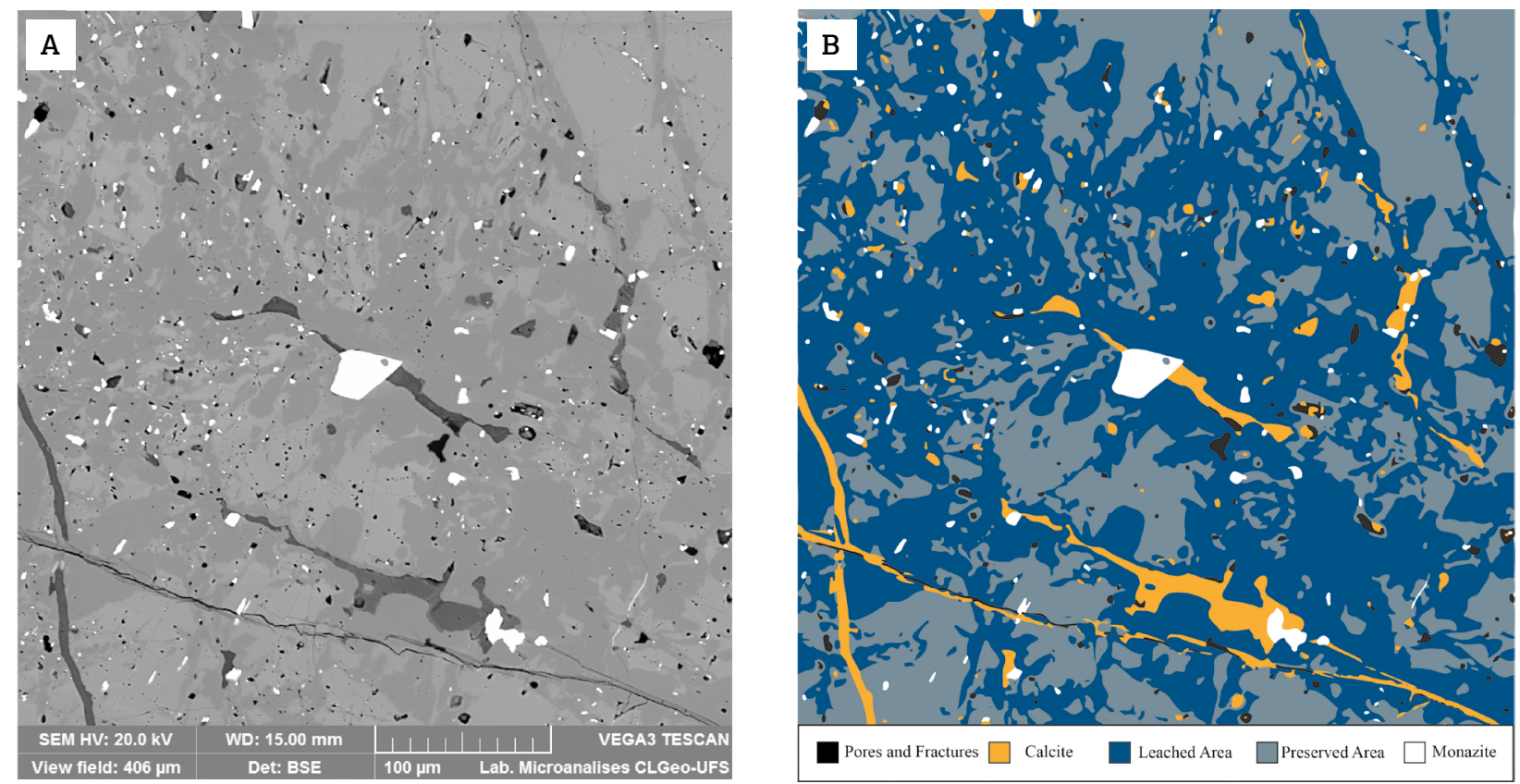

Figure 7. Partially leached apatite crystals in the Floresta Azul Alkaline Complex (FAAC) granites showing monazite precipitation in pores and fractures along areas depleted in rare earth element (REE) + Si and fractures filled with calcite. (A) Back-scattered electrons. (B) False color image of image (A) and highlights the leached (blue) and unleached (gray) sections of an apatite crystal. 

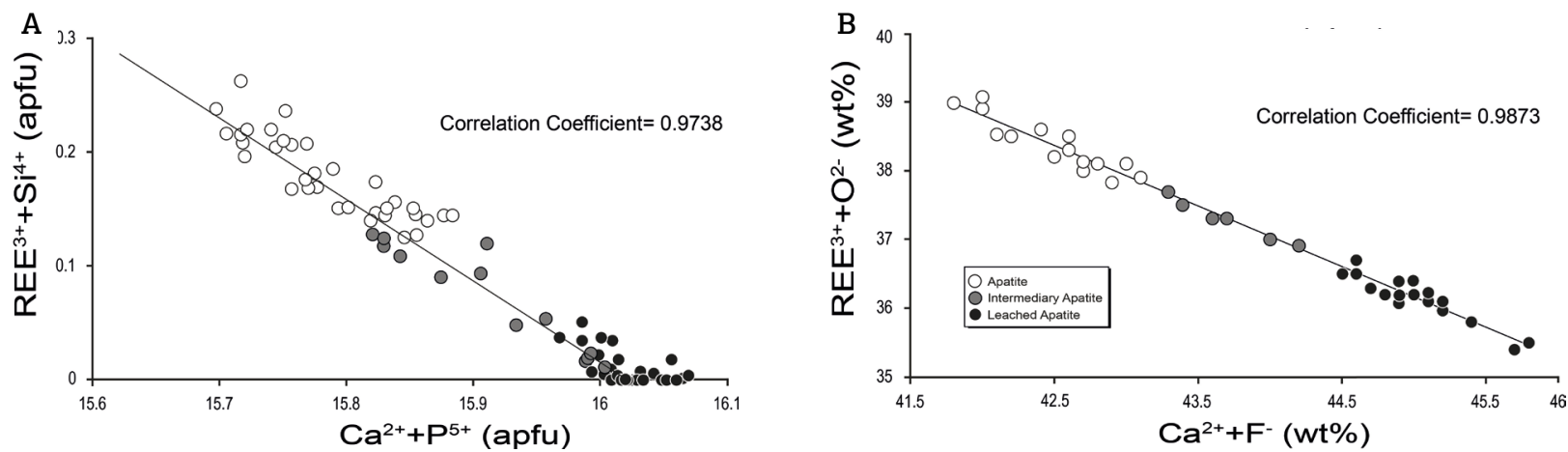

Figure 8. (A) Variations of $(\mathrm{REE}+\mathrm{Si})$ versus $(\mathrm{Ca}+\mathrm{P})$ and $(\mathrm{B})(\mathrm{REE}+\mathrm{O})$ versus $(\mathrm{Ca}+\mathrm{F})$ for the studied apatite crystals.

\section{CONCLUSIONS}

Monazite crystals from the FAAC rocks are characterized by REE abundances ranging from 71.6 to 72.7 $\mathrm{wt} \%$ with predominant monazite-(Ce), whereas monazite(La) has been found only in nepheline syenite. In the studied monazite crystals, $\mathrm{La} / \mathrm{Nd}$ ratios are higher $(2.4$ to 10.6) than those in the monazite crystals of carbonatites. Monazite is rare in fenite, and its REE content is lower than that of granite and syenite, ranging between 68 and 69.2 wt $\%$.

The genesis of monazite crystals in the FAAC syenites and granites is closely related to fluids in two different processes. In the nepheline syenite, late magmatic fluids containing $\mathrm{CO}_{2}$ and $\mathrm{Cl}$ account for the formation of cancrinite and sodalite from nepheline. These fluids also transported REE and crystallized monazite and ancylite. Crystallization of monazite in these rocks was a late magmatic process simultaneous to formation of apatite and ancylite. Monazite was formed in the granite by the interaction between a $\mathrm{CO}_{2}$-rich fluid and apatite crystals. In this process, REE was leached out from apatite with correspondent formation of anhedral crystals of monazite in the regions poor in $\mathrm{REE}+\mathrm{Si}$, which therefore are of metasomatic origin. The substitutions identified in this study for this process are "REE $+\mathrm{Si}=\mathrm{Ca}+\mathrm{P}$ " and " $\mathrm{REE}+\mathrm{O}=\mathrm{Ca}+\mathrm{F}$ ".

In the fenites, monazite is included in crystals of chemically homogeneous apatite in which REE content is lower than that of FAAC nepheline syenite and granite. Monazite is elongated and always oriented along the c-axis of apatite crystals. In the literature, these features are reported as common to monazite crystals formed by apatite exsolution during metamorphism/metasomatism.

\section{ACKNOWLEDGEMENTS}

This study was financed in part by the Coordenação de Aperfeiçoamento de Pessoal de Nível Superior - Brasil (CAPES) - Finance Code 001. The authors would like to acknowledge the support received from the Laboratório da Microssonda Eletrônica of the Geosciences Institute of Universidade de Brasília and the Condomínio dos Laboratórios Multiusuários das Geociências of the Universidade Federal de Sergipe. We express our gratitude to Dr. Nilson Franscisquini Botelho, Dr. Ignez de Pinho Guimarães, and Dr. Débora Correa Rios for critical reviews. The authors also would like to acknowledge to Msc. Paulo César D'Ávila Fernandes for reviewing the text translation. The execution of this research project has been possible thanks to funding from the National Council for Scientific and Technological Development (CNPq) and the Sergipe State Agency for the Advancement of Research and Technological Innovation (FAPITEC), under the project numbers: 019.203.02538/2009-7 (PRONEX/FAPITEC/ CNPq), 311008/2017-8 (CNPq-PQ), 310391/2017-2 (CNPq-PQ), 473013/2012-4 (CNPq-Universal 2013) and 311008/2017-8 (CNPq-Universal 2016).

\section{REFERENCES}

Alderton D.H.M., Pearce J.A., Potts P.J. 1980. Rare earth element mobility during granite alteration: evidence from south-west England. Earth and Planetary Science Letters, 49(1):149-165. https://doi.org/10.1016/0012-821X(80)90157-0
Budzyn B., Hetherington C.J., Williams M.L., Jercinovic M.J., Michalik M. 2010. Fluid-mineral interactions and constraints on monazite alteration during metamorphism. Mineralogical Magazine, 74(4):659-681. https://doi.org/10.1180/minmag.2010.074.4.659 
Chakhmouradian A.R., Mitchell R.H. 1998. Lueshite, pyrochlore and monazite-(Ce) from apatite-dolomite carbonatite, Lesnaya Varaka complex, Kola Peninsula, Russia. Mineralogical Magazine, 62(6):769782. https://doi.org/10.1180/002646198548151

Conceição H., Rosa M.D.L., Moura C.A., Macambira M.J.B., Galarza M.A., Rios D.C., Marinho M.M., Menezes R.C.L., Cunha M.P. 2009. Petrology of the Neoproterozoic Itarantim nepheline syenite batholith, São Francisco Craton, Bahia, Brazil. The Canadian Mineralogist, 47(6):1527-1550. https://doi.org/10.3749/canmin.47.6.1527

Cunha M.P. 2003. Litogeoquímica dos sodalita sienitos da Província Alcalina do Sul do Estado da Bahia. MS Dissertation, Instituto de Geociências, Universidade Federal da Bahia, Salvador, 88 p.

Deer W.A., Howie R.A., Zussman J. (Eds.). 1992. An Introduction to the Rock-Forming Minerals. $2^{\text {nd }}$ ed. London, Longman, v. 2, 696 p.

Finger F., Krenn E. 2007. Three metamorphic monazite generations in a high-pressure rock from the Bohemian Massif and the potentially important role of apatite in stimulating polyphase monazite growth along a PT loop. Lithos, 95(1-2):103-115. https://doi.org/10.1016/j. lithos.2006.06.003

Fleischer M.W., Altschuler Z.S. 1969. The relationship of the rare-earth composition of minerals to geologic environment. Geochimca Cosmochimca Acta, 33(6):725-732. https://doi. org/10.1016/0016-7037(69)90118-5

Fleischer M.W, Rosenblum S., Woodruff M. 1990. The distribution of lanthanides and ytrium in the minerals of the monazite family. Open-File Report, 91-580:1-125. https://doi.org/10.3133/ofr91580

Foerster H.J. 1998. The chemical composition of REE-Y-Th-U-rich accessory minerals in peraluminous granites of the ErzgebirgeFichtelgebirge region, Germany, Part I: The monazite-(Ce)-brabantite solid solution series. American Mineralogist, 83(3-4):259-272. https://doi.org/10.2138/am-1998-3-409

Harlov D.E. 2015. Apatite: A fingerprint for metasomatic processes. Elements, 11(3):171-176. https://doi.org/10.2113/ gselements.11.3.171

Harlov D.E., Andersson U.B., Förster H.J., Nyström J.O., Dulski P., Broman C. 2002. Apatite-monazite relations in the Kiirunavaara magnetite-apatite ore, northern Sweden. Chemical Geology, 191(13):47-72. https://doi.org/10.1016/S0009-2541(02)00148-1

Harlov D.E., Förster H.J. 2002. High-grade fluid metasomatism on both a local and a regional scale: the Seward Peninsula, Alaska, and the Val Strona di Omegna, Ivrea-Verbano Zone, Northern Italy. Part I: petrography and silicate mineral chemistry. Journal of Petrology, 43(5):769-799. https://doi.org/10.1093/ petrology/43.5.769

Harlov D.E., Förster H.J. 2003. Fluid-induced nucleation of (Y+ REE)phosphate minerals within apatite: Nature and experiment. Part II. Fluorapatite. American Mineralogist, 88(8-9):1209-1229.

Harlov D.E., Wirth R., Förster H.J. 2005. An experimental study of dissolution-reprecipitation in fluorapatite: fluid infiltration and the formation of monazite. Contributions to Mineralogy and Petrology, 150(3):268-286. https://doi.org/10.1007/s00410-005-0017-8

Harrison T.M., McKeegan K.D., LeFort P. 1995. Detection of inherited monazite in the Manaslu leucogranite by $208^{\mathrm{Pb}} / 232^{\text {Th }}$ ion microprobe dating: crystallization age and tectonic implications. Earth and Planetary Science Letters, 133(3-4):271-282. https://doi. org/10.1016/0012-821X(95)00091-P

Kelsey D.E., Clark C., Hand M. 2008. Thermobarometric modelling of zircon and monazite growth in melt囚bearing systems: Examples using model metapelitic and metapsammitic granulites. Journal of Metamorphic Geology, 26(2):199-212. https://doi. org/10.1111/j.1525-1314.2007.00757.x
Kim S.J., Lee H.K., Yin J., Park J.K. 2005. Chemistry and origin of monazites from carbonatite dikes in the Hongcheon-Jaeun district, Korea. Journal of Asian Earth Sciences, 25(1):57-67. https://doi. org/10.1016/j.jseaes.2004.01.008

Linthout K. 2007. Tripartite division of the system 2REEPO $-\mathrm{CaTh}\left(\mathrm{PO}_{4}\right)$ 2-2 $\mathrm{ThSiO}_{4}$, discreditation of brabantite, and recognition of cheralite as the name for members dominated by CaTh $\left(\mathrm{PO}_{4}\right)_{2}$. The Canadian Mineralogist, 45(3):503-508. https://doi.org/10.2113/gscanmin.45.3.503

Martins A.A.M., Santos R.A. 1997. Ibicaraí da Folha SD.24-YB-V. Escala 1:100.000. Texto explicativo. Brasília, Programa de Levantamentos Geológicos Básicos do Brasil, CPRM, 256 p.

Montel J.M. 1993. A model for monazite/melt equilibrium and application to the generation of granitic magmas. Chemical Geology, 110(1-3):127-146. https://doi.org/10.1016/0009-2541(93)90250-M

Newbury D.E. 2009. Mistakes encountered during automatic peak identification of minor and trace constituents in eletctron-excited energy dispersive X-ray microanalysis. Scanning, 31(3):91-101. https://doi.org/10.1002/sca.20151

Ni Y., Hughes J.M., Mariano A.N. 1995. Crystal chemistry of the monazite and xenotime structures. American Mineralogist, 80(12):21-26. https://doi.org/10.2138/am-1995-1-203

Nickel E.H. 1992. Solid solutions in mineral nomenclature. Mineralogy and Petrology, 46(1):49-53.

Overstreet W.C. 1967. The Geological Occurrence of Monazite No. 530. United States: US Geological Survey, 327 p.

Pan Y., Fleet M.E. 2002. Compositions of the apatite-group minerals: substitution mechanisms and controlling factors. Reviews in Mineralogy and Geochemistry, 48(1):13-49. https://doi.org/10.2138/rmg.2002.48.2

Pell J. 1994. Carbonatites, nepheline syenites, kimberlites and related rocks in British Columbia. British Columbia, Geological Survey Branch.

Platt R.G., Wall F., Williams C.T., Woolley A.R. 1987. Zirconolite, chevkinite and other rare earth minerals from nepheline syenites and peralkaline granites and syenites of the Chilwa Alkaline Province, Malawi. Mineralogical Magazine, 51(360):253-263. https:// doi.org/10.1180/minmag.1987.051.360.07

Rapp R.P., Watson E.B. 1986. Monazite solubility implications for the felsic magmas and dissolution kinetics: thorium and light rare earth chemistry. Contributions to Mineralogy and Petrology, 94(3):304316. https://doi.org/10.1007/BF00371439

Rønsbo J.G. 1989. Coupled substitutions involving REEs and Na and $\mathrm{Si}$ in apatites in alkaline rocks from the Ilimaussaq intrusion, South Greenland, and the petrological implications. American Mineralogist, 74(7-8):896-901.

Rosa M.L.S., Conceição H., Macambira M.J.B., Galarza M.A., Cunha M.P., Menezes R.C.L., Marinho M.M., Cruz Filho B.E., Rios D.C. 2007. Neoproterozoic anorogenic magmatism in the Southern Bahia Alkaline Province of NE Brazil: $\mathrm{U}-\mathrm{Pb}$ and $\mathrm{Pb}-\mathrm{Pb}$ ages of the blue sodalite syenites. Lithos, 97(1-2):88-97. https://doi.org/10.1016/j.lithos.2006.12.011

Rosa M.L.S., Conceição H., Macambira M.J.B., Marinho M.M., Marques L.S. 2003. Idade ( $\mathrm{Pb}-\mathrm{Pb})$ e aspectos petrográficos e litogeoquímicos do Complexo Floresta Azul, Sul do Estado da Bahia. Revista Brasileira de Geociências, 33(1):13-20.

Santos J.J.A. 2016. Intrusão Sienítica do Complexo Alcalino Floresta Azul, Bahia: mineralogia e geoquímica. MS Dissertation, PósGraduação em Geociências e Análises de Bacias, Universidade Federal de Sergipe, São Cristóvão, 200 p.

Schettler G., Gottschalk M., Harlov D.E. 2011. A new semi-micro wet chemical method for apatite analysis and its application to the crystal chemistry of fluorapatite-chlorapatite solid solutions. American Mineralogist, 96(1):138-152. https://doi.org/10.2138/am.2011.3509 
Teixeira L.M., Botelho N.F. 2002. Comportamento cristaloquímico de monazita primária e hidrotermal durante a evolução de granitos e greisens: exemplos das subprovíncias Tocantins e Paranã, Goiás. Revista Brasileira de Geociências, 32(3):335-342.

Toledo M.C.M., Oliveira S.M.B., Fontan F., Ferrari V.C., Parseval P. 2004. Mineralogia, morfologia e cristaloquímica da monazita de Catalão I (GO, Brasil). Revista Brasileira de Geociências, 34(1):135146. https://doi.org/10.25249/0375-7536.2004341135146
Wark D.A., Miller C.F. 1993. Accessory mineral behavior during differentiation of a granite suite: monazite, xenotime and zircon in the SweetwaterWashpluton, southeastern California,USA.Chemical Geology, 110(1-3):49-67. https://doi.org/10.1016/0009-2541(93)90247-G

Zhu X.K., O'Nions R.K. 1999. Zonation of monazite in metamorphic rocks and its implications for high temperature thermochronology: a case study from the Lewisian terrain. Earth and Planetary Science Letters, 171(2):209-220. https://doi.org/10.1016/S0012-821X(99)00146-6 